\title{
Impacts of Ownership Structure on Systemic Risk of Listed Companies in Vietnam
}

\author{
Van Thi Thuy VU*, Nghia Trong PHAN**, Hung Ngoc DANG ${ }^{* * *}$ \\ Received: December 3, 2019 Revised: December 18, 2019 Accepted: December , 2019
}

\begin{abstract}
The research objective of the paper is to clarify the factors influencing system risks of listed companies in Vietnam, with a focus on clarifying the relationship and quantifying the impacts of ownership structure on systemic risk of listed companies. The data used in this study included financial statements and stock price data of listed companies on the Ho Chi Minh City Stock Exchange and Hanoi Stock Exchange of Vietnam stock market in the period from 2010 to 2017. The paper used the method of estimation in establising the regression models to choose among three models: Random Effect Model, Fixed Effect Model or Pooled OLS for regression using Stata statistical software. The research results showed that state ownership and ownership by foreign investors were positively related to systemic risk, while ownership by domestic investors had a reverse relationship with systemic risk of listed companies in Vietnam. In addition, as a control variable, both company size and profitability had an effect on the systemic risk of listed companies in the research sample. Based on the research results, the authors interpreted some of the implications in order to minimize systemic risks in the operation of listed companies in Vietnam.
\end{abstract}

Keywords : Ownership Structure, Systemic Risk, Listed Companies, Vietnam.

JEL Classification Code: G01, G30, G32, G33

\section{Introduction}

Performance of enterprises played an important role in promoting the growth and development of the economy. In recent years, there has been an increase in the number and the size of enterprises in Vietnam as well as improvement in their performances. Studies showed that listed companies in general and equitized state-owned enterprises in particular have made significant improvement in operational efficiency, improved their corporate governance according to international practices, which created a positive change in the operation of listed companies. However, the performance of the company always entails potential risks that may arise

\footnotetext{
* Corresponding Author: Lecturer, [A1 Building 909, School of Banking and Finance, National Economics University, 207 Giai Phong Street, Hai Ba Trung District, Hanoi, 100000, Vietnam]. Tel.: +84904 133631 Email: thuyvan1507@gmail.com

** Lecturer, Quy Nhon University, Vietnam.

Email: phantrongnghia@qnu.edu.vn

*** Lecturer, Hanoi University of Industry, Vietnam.

Email: hungdangngockt@yahoo.com

(c) Copyright: Korean Distribution Science Association (KODISA)

This is an Open Access article distributed under the terms of the Creative Commons Attribution NonCommercial License (htps://creativecommons.org/licenses/by-nc/4.0/) which permits unrestricted noncommercial use, distribution, and reproduction in any medium, provided the original work is properly cited.
}

from the company itself or from external factors caused by the whole market element. In the context of the current globalization and intensive international integration, companies need to limit negative impacts and systemic risks caused by market factors and properly control the risks caused by internal factors belonging to the characteristics of the company.

Studies (Kim \& Shi, 2009; Lee \& Jang, 2007; Alaghi, 2011) showed that systemic risk was caused by macro factors outside the company such as: political factors, speed economic growth, interest rate, inflation, government macroeconomic policy manipulation, market volatility, competitors,... and also risks caused by specific factors of the company such as: ownership structure of the company, corporate governance characteristics, financial structure, technology, etc. The risks of the business are affected by many factors, in which the ownership structure is an important factor which, through the ownership structure, can increase or limit the risks in the performance of the company. The diversity in the ownership structure of companies created a positive change in improving the performance efficiency of businesses in Vietnam during the past time. Therefore, studying the impact of the ownership structure on 
systemic risks of listed companies in Vietnam is a necessarily supplymentary research.

The research objective of the paper is to clarify the factors influencing system risks of listed companies in Vietnam, with a focus on clarifying the relationship and quantifying the impacts of ownership structure on systemic risk of listed companies. In addition, the research results drawn from listed companies in Vietnam will add more evidence of the relationship between the ownership structure and the systemic risk of companies in a developing country. The research results also provide some implications in governance issues for joint stock companies (especially companies with state ownership); implications for investors in analyzing and making investment decisions; and implications for the stock market regulators to limit the effects of systemic risks on the performance of enterprises in Vietnam.

\section{Literature Review}

\subsection{The Ownership Structure}

The ownership structure is an important determinant of corporate governance and it affects the performance of the company. The ownership structure helps improve information in stock prices; enhance the corporate governance and increase the quality of information published by the company (He, Li, Shen, \& Zhang, 2013); which facilitates solving problems of representatives in the operation of listed companies and limit information asymmetry issues in the stock market; enables to reduce the costs in collecting information and thereby reduce transaction costs for investors. The ownership structure helps enhance the corporate governance and thereby improve the information environment of the company or through mechanisms based on the information advantages of some investors transactions based those obtained information advantages to limit the degree of stock synchronicity compared to that of the overall market and thereby limit the systemic risk of the market. The ownership structure was approached in two aspects: ownership concentration - ownership of the major shareholder and ownership mix (Nguyen, Tran, Dinh, Lai, \& Pham, 2015).

According to the studies of Kiruri (2013), Wen (2010), Anstoniadis et al. (2010), and Kim, Rasinh, and Tasnim (2012), the concept of the ownership mix includes the ownership ratio of shareholders such as: state ownership, ownership by foreign investors and private ownership. In this paper, the authors approached the concept of the ownership structure through the following forms of ownership: State ownership, ownership by foreign investors and domestic shareholders. The impact of the ownership structure on the systemic risk of enterprises through the mechanism of corporate governance improvement. The ownership structure can help companies to manage better (improve risk management, increase performance efficiency and transparency in information disclosure), which enhance the quality and quantity of characterisitc information of the company disclosed to external investors. As a result, investors can establish price evaluation and investment decisions based on specific company information instead of general market information, thereby limiting the stock price synchronicity of the company compared to the overall volatility of the market and systemic risks of the market.

The research conducted by Nguyen et al. (2015) showed that weak corporate governance was attributed to resulting tin systemic risk in the market. Thus, better corporate governance helped reduce systemic risk for the operation of listed companies. From a micro-perspective, the ownership structure is an important factor affecting the company's systemic risk in the market. The ownership structure has an influence on the corporate governance performance and the corporate information environment such as limiting disclosure of adverse information about the company's performance, interfering with the establishment of financial statements, conducting profit adjustment actions, taking advantage of information and trade stocks based on information advantages. The ownership structure of companies in developing countries is characterized by the concentration of founders, financial institutions or state ownership in the form of the ownership by major shareholders. It was this characteristic of ownership structure that created the information advantages for major shareholders, as well as for controll shareholders to manipulate and profit for themselves, also harming the interests of other shareholders. This ownership feature generated the motive for control shareholders to cover up the adverse and information, restrict the information disclosure and thus make the corporate information environment less transparent. A less transparent corporate information environment would make the company's stock price volatility depend mainly on general market information, thereby increasing systemic risk in the market.

\subsection{Systemic Risks of Listed Companies}

According to the traditional approach, the risk on the stock market is divided into two groups:

- Systematic risk : is the risk that has impacts on every sector, fields or types of assets and cannot be excluded based on the the diversification of investment portfolios.

- Unystematic risk: is the risk that only affects one or several sectors, fields or certain types of assets and can be 
ruled out based on the diversification of investment portfolios.

However, the world financial crisis in 2008 showed that the trust in the stability of the financial system is no longer sustainable. After this crisis, researchers around the world focused on how to explain the causes and assess the impact of those crises. The abundance and diversity of studies showed that financial instability proved to be a major challenge for researchers. In particular, the majority of studies showed the need to establish a macro policy, focusing on the improvement of the sustainability of the financial system rather than addressing the consequences caused by the crisis. This demand formed a new research area in the research system of managers in the world on systematic risk. MES indicators of Acharya, Pedersen, Philippon, and Richardson (2010) and the CoVaR method of Adrian and Brunnermeier (2008) shifted from stylistic analysis with the theory of spreading mechanism to a more practical approach. The new concept called "systemic risk" was introduced.

The difference between "systematic risk" and "systemic risk" is clearly reflected in the studies. In particular, "systematic risk" is a risk caused by the weakening of market structure derived from the interest rate fluctuations, war, politics, ... and cannot be ruled out based on the diversification (Amit \& Livnat, 1988; Brunnermeier, Goodhart, Crocket, Persaud, \& Shin, 2009). Meanwhile, "systemic risk" is understood as a risk when financial instability becomes widespread and weakens the functions of the financial system to the extent that it causes material damage to the economic growth and social welfare. The systemic risk reflects the direct failure of microprudential monitoring and also raises the role of macroprudential controlling. In the scope of the study, the article focused on clarifying the systematic risk in the second way: "systemic risk".

Unlike "systematic risk" - a widely accepted and popular concept in research, "systemic risk" (hereinafter referred to as systemic risk) is only concerned and widely mentioned since the global financial crisis in 2008. Previously, financial intermediaries or economies rarely mentioned the definition of systemic risk. Central banks or markets often focused on studying the financial stability rather than financial crisis or systemic risk. (Oosterloo \& de Haan, 2003).

Initially, the view of the systemic risk did not reach any common consensus among researchers. In fact, before that, systemic risk and systematic financial crises had not been fully integrated into macroeconomic models. Therefore, systemic risk was not explicitly mentioned in models that predicted the economic trends and guided the policy decisions. Systemic risk had a variety of expressions, depending on the field of research and risk management organizations.

According to Bordo, Mizrach, and Schwartz (1998, p.31): "Systemic risk relates to the shocks to a part of the financial system, which in turn results in shocks affecting other components and having impacts on the stability of the real economy". Meanwhile large organizations such as IMF/BIS/FSB described systemic risk as a risk of financial service disruption. According to these organizations, systemic risk: (i) was caused by the weakening of the whole or part of the financial system and (ii) tended to cause seriously negative consequences for the real economy. Subsequently, the International Association for Insurance Supervision (IAIS) added two elements to the IMF/BIS/FSB definition: "A decline or disruption of financial service flow will include the situations where certain financial services are not provided, or the cost of financial services is rising sharply".

However, according to IOSCO (2012), systemic risk, in the context of the stock market, did not stop at sudden catastrophic events; it might also indicate the distrust in the market. This approach focused on a narrow definition of systemic risk that could intervene earlier, especially in stock markets where new trends were often present, gaps and initial risks might not be systematic, but due to the size or specific circumstances, it created systemic risk. In particular, securities products may lead to "a gradual erosion of trust in the market" in the case of other factors being dissatisfied, such as unstable risk management (weak risk management often considered the main cause of the collapse of Lehman Brothers).

In summary, systemic risk can be derived from any factor of the economy. This means that a financial tool, institution, market, market infrastructure or segment of the financial system can be the root of systemic risk, spreading the systemic risk, as well as being affected by it. It is not easy to determine whether the scale of an event can become a systemic risk or not, as in the period of volatile market, the assessment of the impact on market components can be inaccurate and misleading. Systemic risk can be derived internally or outside the financial system or it may be the result of a connection among financial intermediaries and specific financial markets as well as their exposure to the economy. real (Szpunar, 2012).

\subsection{Impacts of Ownership Structure on Systemic Risk of Listed Companies}

Morck, Yeung, and Yu (2000) and Jin and Myers (2006) showed that ownership structure had an impact on the transparency in information disclosure as well as protection of investors and in developing countries with a less transparent information environment, the limitation in 
investor protection would increase systemic risk for listed companies. Brockman and Yan (2009) showed that ownership by major shareholders increased the liquidity and reflected more specific information of the company into stock prices, thereby limiting systemic risk of the market. Major shareholders had access to more accurate information, collected information belonging to the company's characteristics at a lower cost than others. The ownership by major shareholders will lead to more reflection of the company's specific information in stock prices and limit the influence of the general market information on stock prices. The research results of Brockman and Yan (2009) reinforce the findings of Morck et al. (2000), which through the supervisory role of major shareholders will limit the risk of information discrepancies and restrict the operation of price difference trading activities on the stock market.

An and Zhang (2013) argued that a major shareholder being an institutional investor would take control and supervise the activities of listed companies and often made long-term investment. Strict supervision of the major shareholder being the institutional investor will help managers strengthen the cash flow management of the company, which reduced the synchronicity of stocks against the market and thereby limiting systemic risks. In contrast, the study by Fernandes and Ferreira (2008) and Kim and Shi (2009) showed that the causes of higher volatility in emerging markets compared to developed ones lay in the corporate ownership structure in emerging markets being characterized by ownership concentration by family members or state ownership. In the non-transparent information environment, shareholders holding control had more motives to cover up the adverse information in the operations of the company (or limitedly published information to the external investors) with a view to serving their own interests. This led to an increase in synchronocity of the company with general market volatility and thereby raising systemic risk.

The research conducted by Jiang and Kim (2004) revealed that ownership by foreign investors had a reverse relation with information asymmetry. In addition, foreign ownership helped improve the quality of information on the domestic stock market in the context of proper corporate governance environment, and thus significantly reduced transaction costs and risks (Li et al., 2011). Studies carried out by Kim and Yi (2009), Gul, Kim, and Qiu (2010), and He and Shen (2014) represented that foreign investors often had better governance and greater management experience therefore helped increase the transparency of the company and made it easier for investors in the market to access characteristic information of the company, thereby reducing synchronocity of the company's stock price and lessening the market systemic risk.
The research conducted by Gul et al. (2010) and Hou, Kuo, and Lee (2012) provided evidence showing that high state ownership led to the limitations in protecting the interests of minority shareholders and disclosure of unclear financial statements, and therefore, increasing the synchronocity of stock prices and systemic risks in the market. The research carried out by Hamdi and Cosset (2014) made it clear that high ratio of state ownership often resulted in a less transparent corporate information environment, causing difficulties and more costs for the collection of specific corporate information, and therefore it did not encourage investors to gather characteristic information of the company. As a result, little specific information of the company was converted into stock prices, which increased the synchronicity of the company's stock price in comparison to the volatility of the whole market and thereby increasing systemic risks of the market.

In general, those studies represented the existence of a relationship between ownership structure and systemic risk through the synchronocity in the company's stock price compared to the general market volatility, the effect of ownership structure on corporate governance, information environment as well as information advantages of certain ownership groups and thereby influencing systemic risk of the stock market. However, studying the impact of ownership structure and the factors of company characteristics on the risks of listed companies in Vietnam has not been properly conducted.

\section{Research Methods}

\subsection{Data}

The data used in this study included financial statements and stock price data of listed companies on the Ho Chi Minh City Stock Exchange and Hanoi Stock Exchange under Vietnam stock market in the period from 2010 to 2017. Data were provided by StoxPlus Company which specializes in collecting and analyzing financial data in Vietnam.

\subsection{Variables in the Model}

First of all, based on the collected data, the research team calculated the necessary criteria for the study by using Microsoft Excel software. Then, the data were processed by Stata statistical software according to the array data model. Analyses of correlation, multicollinearity and statistics describing variables in the model were implemented. Next, the authors used the method of estimation in establising the regression models to choose among three models: Random 
Effect Model, Fixed Effect Model or Pooled OLS for regression using Stata statistical software.

\subsubsection{Dependent Variable}

To assess the impacts of stocks upon risk events, the authors used the CoVaR method by Adrian and Brunnermeier (2008) proposed in 2008 in NY Fed Staff Reports. This report was then revised in 2009, 2010, 2014 and 2016. CoVaR is a method of measuring the level of adverse impact on the financial system upon insolvency. CoVaR is built on the basis of VaR method (Value At Risk), acoustically "' Co "in CoVaR is put forth by the author of the method.

The process of measuring the VaR of the entire market in the context of listed companies experiencing liquidity difficulties and/or in the context of lower market value of assets than that of the company's own debt. How the process of measuring $\mathrm{VaR}$ of the whole stock market will change in the context of listed companies having lower market value of assets than that of debts and in the situation of insolvency.

Value $\operatorname{VaR}_{q}^{i}$ determined at $\% \mathrm{q}$ is described in the equation:

$$
P_{r}\left(X^{i}<\operatorname{VaR} R_{q}^{i}\right)=q \%
$$

$V_{a} R_{q}^{i}$ indicates the maximum value and likelihood of occurrance within a certain time range.

$\operatorname{CoVaR}_{q}^{j \mid C\left(X^{i}\right)}$ is defined as the VaR of total assets according to the market value of the stock market $\mathrm{j}$ in case company $i$ falls into the status of insolvency. And CoVaR is determined based on conditional probability equation:

$$
P_{r}\left(X^{j} \mid C\left(X^{i}\right)<\operatorname{CoVaR}_{q}^{j \mid C\left(X^{i}\right)}\right)=q \%
$$

$X^{i}$ : is understood as the fluctuation of the asset market value of the company $i$ and of the stock of listed company $i$. $\mathrm{X}$ is determined as follows:

$$
\mathrm{Xti}=(\text { MVAti }- \text { MVAit-1)/MVAit-1 }
$$

In which:

MVA is the market value of asset: MVA = BVA*(MVE/BVE)

BVA: Book value

BVE: Equity

MVE: Capitalization value $=$ Stock price* number of outstanding shares
Based on equation $(* 1)$ and (*2), $\operatorname{CoVaR}_{q}^{j \mid C\left(X^{i}\right)}$ can be expressed as the $\mathrm{VaR}$ value of the market volatility at the level of $q \%$ in the event of volatility in the asset market value of the organization $i$ at the level of $\mathrm{VaR}$ at $q \%$.

Research data were initially screened and eliminating stock codes with a listing period of less than 8 years to ensure regression theory (the minimum number of observations is 30 ). Data after screening included 185 stock codes corresponding to 185 monthly MVA value chains in the period from 2010 to 2017 .

The variables that were applied included: (1) Macroeconomic variable group and (2) The overall growth rate of the asset market is the total market value of assets of listed companies, $\mathrm{Xj}$

Step 1: Test stationary series

Step 2: Perform quantile regression based on monthly data in accordance with the following equation:

$$
\begin{aligned}
& X_{t}^{i}=\propto_{q}^{i}+\gamma_{q}^{i} M_{t-1}+\varepsilon_{q, t}^{i} \\
& X_{t}^{j \mid i}=\propto_{q}^{j \mid i}+\gamma_{q}^{j \mid i} M_{t-1}+\beta_{q}^{j \mid i} X_{t}^{i}+\varepsilon_{q, t}^{j \mid i}
\end{aligned}
$$

After conducting regression according to equation $(* 3)$ and $(* 4)$ above, the calculation of values of $\operatorname{VaR}_{t}^{i}(q), \operatorname{CoVaR}_{t}^{i}(q)$ and $\Delta \operatorname{CoVaR}_{t}^{i}(q)$ were carried out in accordance with the following equations:

$$
\begin{aligned}
& \operatorname{VaR}_{q, t}^{i}=\propto_{q}^{i}+\gamma_{q}^{i} M_{t-1} \\
& \operatorname{CoVaR}_{q, t}^{i}=\propto_{q}^{j \mid i}+\beta_{q}^{j \mid i} \operatorname{VaR}_{q, t}^{i}+\gamma_{q}^{i} M_{t-1}
\end{aligned}
$$

Step 3: Continue to perform Ramsey tests to ensure the reliability of regression coefficients and function forms.

The selection of macroeconomic variable groups was essential in the study of systemic risk. The macroeconomic event is one of the triggering ones that can lead to risks of the whole stock market as well as the financial system. Therefore, the process of selecting macro variables was based on the theory of stock yields, an overview of domestic and foreign measures related to stock market and based on qualitative research.

According to Adrian and Brunnermeier (2008) macro variables were determined based on the following criteria: (1) a direct impact on the chronical variation of the asset value in the economy, (2) variables' capability of describing liquidity in the economy, and (3) convenience for future tracking. The total number of macro variables was limited to ensure that Overfitting phenomenon wouldn't occur and that macro variables are selected based on the appropriate time period for the entire research model, including: 
$\checkmark \quad$ Difference of government bond yields for 1-year and 10-year term

$\begin{array}{ll}\checkmark & \text { Profit of Vnindex } \\ \checkmark & \text { CDS (Credit Default Swap) } \\ \checkmark & \text { Consumer price index } \\ \checkmark & \text { Money supply } \\ \checkmark & \text { Exchange rate }\end{array}$

\subsubsection{Independent Variable}

Ownership structure, including:

(1) State Ownership (State): Approached according to the research conducted by Hamdi and Cosset (2014), state ownership is defined as the percentage of shares held by the state in any form over the total number of outstanding shares of the company.

(2) Ownership by foreign investors (Foreign): Approached according to the measure of ownership by foreign investors in line with the research of He and Shen (2014), ownership by foreign investors is the proportion of shares held by foreign investors compared to the total outstanding shares of the company at the end of the fiscal year.

(3) Ownership by Domestic investors: Based on the research of He and Shen (2014), the ownership of domestic investors is defined as the ratio of the number of shares held by the investors. domestic investment compared to the total number of outstanding shares of the company at the end of the fiscal year.

Control variables: studying the usage of the two control variables in the model, including:

(1) ROE: Return on equity is determined by the return after tax divided by the bank equity at the end of the calculated year.

(2) SIZE: size of listed company is determined by loganepe of total assets.

According to the research overview, the research team analyzed the impact of ownership structure on systemic risks of listed companies in Vietnam based on the following regression model with table data:

$$
\begin{aligned}
\text { Model 1: CoVaR }= & \beta 0+\beta 1 \text { STATE }+\beta 2 \mathrm{ROE} \\
& +\beta 3 \mathrm{SIZE}+\text { et }
\end{aligned}
$$

$$
\begin{aligned}
\text { Model 2: CoVaR }= & \beta 0+\beta 1 \text { FOREIGN }+\beta 2 \text { ROE } \\
& +\beta 3 \text { SIZE }+ \text { et } \\
\text { Model 3: CoVaR }= & \beta 0+\beta 1 \text { DOMESTIC }+\beta 2 \text { ROE } \\
& +\beta 3 \text { SIZE }+ \text { et } \\
\text { Model 4: CoVaR }= & \beta 0+\beta 1 \text { STATE }+\beta 2 \text { FOREIGN } \\
& +\beta 3 \text { ROE }+\beta 4 \text { SIZE }+ \text { et }
\end{aligned}
$$

\section{Results and Discussion}

\subsection{Descriptive Statistics and Correlation}

Table 1 showed that CoVaR variable had a negative average value $(-0.092)$, the variation of CoVaR value was $2.74 \%$ and the difference between the lowest and the highest value of CoVaR variable was the smallest among the research variables. The STATE variable mean of the companies in the research sample was $21.72 \%$ and that of the company with the highest state ownership was $84 \%$. Likewise, the mean of FOREIGN and DOMESTIC variables were $13.6 \%$ and $63.6 \%$, respectively. Domestic shareholders accounted for a high percentage of ownership in the ownership structure of listed companies in Vietnam. The ROE variable had the minimum value of $-0,063 \%$ and the maximum value of $10.99 \%$; the mean of the return on equity of the companies in the sample was $3.43 \%$ and the spread level of ROE variable was the highest in the studied variables of the model. As an empirical rule, multicollinearity is not a serious problem when the correlation coefficient between the two independent variables is less than 0.8 (Gujarati, 2003) (Table 2).

Table 1: Statistical data

\begin{tabular}{|l|l|l|l|l|}
\hline \multicolumn{1}{|c|}{ Variables } & \multicolumn{1}{c|}{ Mean } & $\begin{array}{c}\text { Standard } \\
\text { Deviation }\end{array}$ & \multicolumn{1}{c|}{ Min } & \multicolumn{1}{c|}{ Max } \\
\hline CoVaR & -0.0920 & 0.0273 & -0.1415 & -0.0355 \\
\hline STATE & 0.2172 & 0.2431 & 01 & 0.84 \\
\hline FOREIGN & 0.1361 & 0.1624 & 0 & 0.89 \\
\hline DOMESTIC & 0.6366 & 0.2729 & 0.02 & 1 \\
\hline ROE & 3.4347 & 3.1385 & -0.0629 & 10.99 \\
\hline SIZE & 14.0788 & 1.3254 & 12.1975 & 16.9629 \\
\hline
\end{tabular}

Table 2: Correlation Matrix

\begin{tabular}{|c|c|c|c|c|c|c|}
\hline & COVAR & STATE & FOREIGN & DOMESTIC & ROE & SIZE \\
\hline COVAR & 1 & & & & & \\
\hline STATE & 0.0312 & 1 & & & & \\
\hline FOREIGN & 0.0274 & -0.1444 & 1 & & & \\
\hline DOMESTIC & -0.0435 & -0.8016 & -0.4758 & 1 & & \\
\hline ROE & 0.0455 & 0.1131 & 0.1152 & -0.1699 & 1 & \\
\hline SIZE & -0.1165 & -0.0621 & 0.3051 & -0.1292 & -0.042 & \\
\hline
\end{tabular}




\subsection{Selecting the Appropriate Model}

\section{Regression with Model 1:}

$\mathrm{CoVaR}=\beta 0+\beta 1 \mathrm{STATE}+\beta 2 \mathrm{ROE}+\beta 3 \mathrm{SIZE}+$ et

For the independent variable that is STATE variable, the authors compared and chose which model would be appropriate: OLS, FEM or REM. To examine and select the appropriate model among the three regression methods above, the author used F-test and Hausman test. With F-test, we saw that Prob $>F=0.000<\alpha=5 \%$, therefore, with a statistical significance level of $5 \%, \mathrm{H} 0$ was rejected. That is, with the data collected, it was shown that the method of running the FEM model was appropriate and that OLS was inappropriate because fixed effects existed in each business over time. After selecting the FEM model instead of the one running OLS, the study team looked into the estimated table data based on the methods of running FEM and REM respectively. Based on the results of running the FEM and REM models, the author team conducted the verification of Hausman to compare the selection between FEM and REM models. The Hausman test results were presented in Table 3. It can be seen that Prob $>$ chi $2=0.000$, i.e $P$ _value $=0.000$ $<\alpha=5 \%$. Therefore, there had sound basis to reject the assumption H0, then the Fixed Effect Models (FEM) proved to be more appropriate than the Random Effect Models (REM). Through testing methods of running models, FEM is the best selected model.

However, before conducting the detailed analysis of the influencing factors on systemic risk, the author proceeded to use the following tests: variance change, autocorrelation and carried out necessary corrections to overcome the limitations of the model.

Testing the autocorrelation: The Wooldridge test method was used to test whether there existed the autocorrelation or not for regression models. The following hypothesis was assumed: H0: the autocorrelation phenomenon was negative; $\mathrm{H} 1$ : the autocorrelation phenomenon was positive. If the test results indicated $\mathrm{P}_{\text {_value }}=0.0000<\alpha=0.05$, the assumption $\mathrm{H} 0$ would be rejected, i.e there would be a phenomenon of autocorrelation.

Testing the variance change: To test whether the variance change existed in the model, the authors used Breusch and Pagan test. With the assumption H0: variance change phenomenon was negative, $\mathrm{H} 1$ : the variance change phenomenon was positive. As the test results for P-value was small (less than 0.05 default), the assumption $\mathrm{H} 0$ would be rejected and H1 hypothesis would be accepted. Based on the results stated in Table 3, the coefficient $\mathrm{P}$ value $<\alpha=0.05$. Therefore, assumption $\mathrm{H} 0$ were rejected. The test results of the model indicated that the obtained Pvalues were all equal to $0.000<\alpha(5 \%)$, which implied that the assumption $\mathrm{H} 0$, in which the variance change phenomenon in the models was negative, was rejected with the significance level of $5 \%$. Thus, the author proceeded to overcome the defects of the regression model by GLS regression method.

Table 3: Regression with Model 1

\begin{tabular}{|c|c|c|c|}
\hline & FEM & REM & GLS \\
\hline \multirow[t]{2}{*}{ L_STATE } & $-0.0156 * * *$ & -0.00374 & 0.00296 \\
\hline & {$[-3.05]$} & {$[-1.11]$} & {$[1.63]$} \\
\hline \multirow[t]{2}{*}{ ROE } & -0.000162 & -0.0000427 & $0.000388^{* * * *}$ \\
\hline & {$[-0.99]$} & {$[-0.27]$} & {$[2.77]$} \\
\hline \multirow[t]{2}{*}{ SIZE } & $0.00985 * * *$ & 0.000681 & $-0.00219 * * *$ \\
\hline & {$[7.75]$} & {$[1.03]$} & {$[-6.67]$} \\
\hline \multirow[t]{2}{*}{ cons } & $-0.227 * * *$ & $-0.101 * * *$ & $-0.0635 * * *$ \\
\hline & {$[-12.61]$} & {$[-10.61]$} & {$[-13.52]$} \\
\hline $\mathrm{N}$ & 3879 & 3879 & 3879 \\
\hline R-sq & 0.019 & & \\
\hline \multirow{2}{*}{$\mathrm{F}$ test } & $\begin{array}{l}\mathrm{F}(3,3742)= \\
24.77\end{array}$ & $\begin{array}{l}\text { Wald chi2(3) } \\
=2.55\end{array}$ & \\
\hline & $\begin{array}{l}\text { Prob > F }= \\
0.0000\end{array}$ & $\begin{array}{l}\text { Prob }>\text { chi2 }= \\
0.4657\end{array}$ & \\
\hline \multirow{2}{*}{ LM test } & & & $\begin{array}{l}\text { Wald chi2(3) } \\
=57.91\end{array}$ \\
\hline & & & $\begin{array}{l}\text { Prob }>\text { chi } 2 \\
=0.0000\end{array}$ \\
\hline \multirow{2}{*}{ Hausman test } & & \multicolumn{2}{|c|}{$\operatorname{chi} 2(3)=92.76$} \\
\hline & & \multicolumn{2}{|c|}{ Prob $>$ chi $2=0.0000$} \\
\hline \multirow{2}{*}{$\begin{array}{c}\text { Breusch and Pagan } \\
\text { Lagrangian }\end{array}$} & & \multicolumn{2}{|c|}{$\operatorname{chi} 2(134)=403.56$} \\
\hline & & \multicolumn{2}{|c|}{ Prob $>$ chi $2=0.0000$} \\
\hline \multirow{2}{*}{ Wooldridge test } & & \multicolumn{2}{|c|}{$\mathrm{F}(1,133)=153.014$} \\
\hline & & \multicolumn{2}{|c|}{ Prob $>$ chi $2=0.0000$} \\
\hline & $\begin{array}{l}\text { t statistics in br } \\
* * * p<0.01\end{array}$ & kets $* \mathrm{p}<0.1, * *$ & $<0.05$ \\
\hline
\end{tabular}

Regression results by GLS: After performing the regression and testing as well as selecting the appropriate model of FEM, the authors proceeded to overcome the defects of the model detected by GLS method (Generalized least squares). The results presented in Table 3 were the outcomes that have overcome the defects of the model. Thus, the research results showed that the size and the profitability both had influence and statistical significance on systemic risk. Meanwhile, the state ownership variable was of no statistical significance.

The process of selecting models no. 2, 3 and 4 was similarly conducted according to the steps of model no.1. The research results were shown in Tables 4, 5 and 6 .

According to the regression results by GLS, models 2 and 3 indicated that foreign ownership, domestic ownership, size and profitability all had an impact on systemic risk. In particular, the variables of foreign ownership and profitability were positively related, whereas domestic ownership and scale variables had reverse effects on systemic risks. 
Table 4: Regression with Model 2.

\begin{tabular}{|c|c|c|c|}
\hline & FEM & REM & GLS \\
\hline \multirow[t]{2}{*}{ L_FOREIGN } & $0.0258 * * *$ & $0.0210^{* * *}$ & $0.0113 * * *$ \\
\hline & {$[4.25]$} & {$[4.52]$} & {$[4.04]$} \\
\hline \multirow[t]{2}{*}{ ROE } & -0.000163 & -0.0000817 & $0.000340 * *$ \\
\hline & {$[-1.00]$} & {$[-0.52]$} & {$[2.43]$} \\
\hline \multirow[t]{2}{*}{ SIZE } & $0.00859 * * *$ & -0.000111 & $-0.00265^{* * *}$ \\
\hline & {$[6.54]$} & {$[-0.16]$} & {$[-7.68]$} \\
\hline \multirow[t]{2}{*}{ cons } & $-0.216 * * *$ & $-0.0933 * * *$ & $-0.0578 * * *$ \\
\hline & {$[-11.81]$} & {$[-9.66]$} & {$[-12.01]$} \\
\hline $\mathrm{N}$ & 3879 & 3879 & 3879 \\
\hline R-sq & 0.022 & & \\
\hline \multirow{2}{*}{ F test } & $\begin{array}{c}\mathrm{F}(3,3742)= \\
27.73\end{array}$ & $\begin{array}{l}\text { Wald chi2(3) } \\
\quad=21.82\end{array}$ & \\
\hline & $\begin{array}{c}\text { Prob }>F= \\
0.0000\end{array}$ & $\begin{array}{c}\text { Prob }>\text { chi } 2= \\
0.0001\end{array}$ & \\
\hline \multirow{2}{*}{ LM test } & & & $\begin{array}{l}\text { Wald chi2(3) } \\
=81.28\end{array}$ \\
\hline & & & $\begin{array}{c}\text { Prob }>\text { chi } 2= \\
0.0000\end{array}$ \\
\hline \multirow{2}{*}{ Hausman test } & & \multicolumn{2}{|c|}{$\operatorname{chi} 2(3)=92.76$} \\
\hline & & \multicolumn{2}{|c|}{ Prob $>$ chi $2=0.0000$} \\
\hline \multirow{2}{*}{$\begin{array}{c}\text { Breusch and } \\
\text { Pagan Lagrangian }\end{array}$} & & \multicolumn{2}{|c|}{$\operatorname{chi} 2(134)=403.56$} \\
\hline & & \multicolumn{2}{|c|}{ Prob $>$ chi $2=0.0000$} \\
\hline \multirow{2}{*}{ Wooldridge test } & & \multicolumn{2}{|c|}{$\mathrm{F}(1,133)=153.735$} \\
\hline & & \multicolumn{2}{|c|}{ Prob $>$ chi $2=0.0000$} \\
\hline
\end{tabular}

Table 5: Regression with Model 3

\begin{tabular}{|c|c|c|c|}
\hline & FEM & REM & GLS \\
\hline \multirow[t]{2}{*}{ L_DOMESTIC } & 0.00632 & -0.00167 & $-0.00544 * * *$ \\
\hline & {$[1.35]$} & {$[-0.54]$} & {$[-3.24]$} \\
\hline \multirow[t]{2}{*}{ ROE } & -0.000192 & -0.0000906 & $0.000273 *$ \\
\hline & {$[-1.16]$} & {$[-0.57]$} & {$[1.89]$} \\
\hline \multirow[t]{2}{*}{ SIZE } & $0.0103^{* * *}$ & 0.000457 & $-0.00253^{* * *}$ \\
\hline & {$[7.94]$} & {$[0.67]$} & {$[-7.44]$} \\
\hline \multirow[t]{2}{*}{ _cons } & $-0.241 * * *$ & $-0.0969 * * *$ & $-0.0538 * * *$ \\
\hline & {$[-12.76]$} & {$[-9.57]$} & {$[-10.43]$} \\
\hline $\mathrm{N}$ & 3716 & 3716 & 3716 \\
\hline R-sq & 0.018 & & \\
\hline \multirow{2}{*}{$\mathrm{F}$ test } & $\begin{array}{c}F(3,3579)= \\
21.68\end{array}$ & $\begin{array}{l}\text { Wald chi2(3) } \\
\quad=1.14\end{array}$ & \\
\hline & $\begin{array}{c}\text { Prob }>F= \\
0.0000\end{array}$ & $\begin{array}{l}\text { Prob }>\text { chi } 2 \\
=0.7668\end{array}$ & \\
\hline \multirow{2}{*}{ LM test } & & & $\begin{array}{c}\text { Wald chi2 } 2(3)= \\
68.15\end{array}$ \\
\hline & & & $\begin{array}{c}\text { Prob }>\text { chi } 2= \\
0.0000\end{array}$ \\
\hline \multirow{2}{*}{ Hausman test } & & \multicolumn{2}{|c|}{$\operatorname{chi} 2(3)=85.13$} \\
\hline & & \multicolumn{2}{|c|}{ Prob $>$ chi $2=0.0000$} \\
\hline \multirow{2}{*}{$\begin{array}{l}\text { Breusch and } \\
\text { Pagan } \\
\text { Lagrangian }\end{array}$} & & \multicolumn{2}{|c|}{$\operatorname{chi} 2(134)=534.44$} \\
\hline & & \multicolumn{2}{|c|}{ Prob $>$ chi $2=0.0000$} \\
\hline \multirow{2}{*}{ Wooldridge test } & & \multicolumn{2}{|c|}{$F(1,133)=151.689$} \\
\hline & & \multicolumn{2}{|c|}{ Prob $>$ chi2 $=0.0000$} \\
\hline
\end{tabular}

In addition, when the research team additionally controlled the variable of ownership by foreign investors in the relations between state ownership and systemic risk to consider the net effect of state ownership on systemic risk, the results showed that state ownership, foreign ownership and profitability were positively related to systemic risks. The results were shown in Table 6:

Table 6: Regression with Model 4

\begin{tabular}{|c|c|c|c|}
\hline & FEM & REM & GLS \\
\hline \multirow[t]{2}{*}{ L_STATE } & $-0.0163^{* * *}$ & -0.00302 & $0.00404 * *$ \\
\hline & {$[-3.20]$} & {$[-0.89]$} & {$[2.21]$} \\
\hline \multirow[t]{2}{*}{$\begin{array}{c}\text { L_FOREIG } \\
\mathrm{N}\end{array}$} & $0.0264 * * *$ & $0.0208^{* * *}$ & $0.0122 * * *$ \\
\hline & [4.35] & [4.47] & [4.31] \\
\hline \multirow[t]{2}{*}{ ROE } & -0.000149 & -0.000073 & $\begin{array}{c}0.000295^{*} \\
*\end{array}$ \\
\hline & {$[-0.91]$} & {$[-0.46]$} & [2.09] \\
\hline \multirow[t]{2}{*}{ SIZE } & $0.00830 * * *$ & -0.000129 & $\begin{array}{c}- \\
0.00265^{* * *}\end{array}$ \\
\hline & [6.31] & {$[-0.19]$} & {$[-7.69]$} \\
\hline \multirow[t]{2}{*}{ _cons } & $-0.209 * * *$ & $-0.0924 * * *$ & $\begin{array}{c}- \\
0.0586^{* * *}\end{array}$ \\
\hline & {$[-11.33]$} & {$[-9.50]$} & {$[-12.14]$} \\
\hline $\mathrm{N}$ & 3879 & 3879 & 3879 \\
\hline R-sq & 0.024 & & \\
\hline \multirow[t]{2}{*}{ F test } & $\begin{array}{c}\mathrm{F}(4,3741)= \\
23.40\end{array}$ & $\begin{array}{c}\text { Wald } \\
\text { chi2 } 2(4)= \\
22.65\end{array}$ & \\
\hline & $\begin{array}{l}\text { Prob }>F= \\
0.0000\end{array}$ & $\begin{array}{l}\text { Prob > chi2 } \\
=0.0001\end{array}$ & \\
\hline \multirow{2}{*}{ LM test } & & & $\begin{array}{r}\text { Wald } \\
\text { chi2(4) } \\
=76.76\end{array}$ \\
\hline & & & $\begin{array}{c}\text { Prob }> \\
\text { chi2 }= \\
0.0000\end{array}$ \\
\hline \multirow{2}{*}{$\begin{array}{l}\text { Hausman } \\
\text { test }\end{array}$} & & \multicolumn{2}{|c|}{$\operatorname{chi} 2(4)=91.92$} \\
\hline & & \multicolumn{2}{|c|}{ Prob $>$ chi $2=0.0000$} \\
\hline \multirow{2}{*}{$\begin{array}{l}\text { Breusch and } \\
\text { Pagan } \\
\text { Lagrangian }\end{array}$} & & \multicolumn{2}{|c|}{$\operatorname{chi} 2(134)=388.21$} \\
\hline & & \multicolumn{2}{|c|}{ Prob $>$ chi $2=0.0000$} \\
\hline \multirow{3}{*}{$\begin{array}{l}\text { Wooldridge } \\
\text { test }\end{array}$} & & \multicolumn{2}{|c|}{$F(1,133)=152.901$} \\
\hline & & \multicolumn{2}{|c|}{ Prob $>$ chi $2=0.0000$} \\
\hline & t statistics & $\begin{array}{l}\text { kets * } p<0.1, \\
* \mathrm{p}<0.01\end{array}$ & $\mathrm{p}<0.05$ \\
\hline
\end{tabular}

\section{Implications of the Research}

The quantitative analysis results indicated that there existed a relations and statistical significance among state ownership, ownership by foreign investors, ownership by domestic investors and systemic risks of listed companies on Vietnam stock market. Based on the research results, the authors interpreted some of the implications as follows: 
In order to minimize systemic risks in the operation of listed companies, the State should divest and gradually reduce the ownership rate in those companies where the State owns capital. The state should focus more on its functions as a regulatory agency to lead the market to operate in a healthy, transparent and effective manner. Intervention and direct participation in the operation of the company should be limited. In addition to gradually reducing the state ownership ratio in listed companies, it is necessary to increase the ownership by foreign shareholders in the form of strategic investors, major shareholders and institutional investors. The State should create a mechanism to facilitate the foreign institutional investors to participate in the purchase of shares and operation of the company to take advantage of the management skills and advantages of foreign investors in the improvement of operational efficiency, enhancement of risk management in the corporate operations and betterment of the corporate information environment.

In addition, those companies with large-scale capital which are majorly loans and with low equity, especially those with large ownership ratios of the State, are susceptible to systemic risks on the market. Therefore, these companies need to further improve risk management in operations, increase the transparency in information disclosure and limit cross-ownership among companies.

\section{Conclusions}

Through the regression method for the table data set of listed companies on Vietnam stock market during the period of 2007-2017, the authors found a positive relation between the ownership by foreign investors and systemic risks on Vietnam stock market. The reverse relations between ownership by domestic investors and market systemic risk. The ownership by foreign investors was positively correlated with systemic risk on the stock market. A fact on Vietnam stock market is that the State encourages foreign investors to participate in holding shares of listed companies through increasing the room of foreign investors. However, for some sectors and fields, the State still controls the foreign ownership, typically in commercial banks, as specified in Article 7, Decree 01/2014 stipulating the total shareholding of foreign investors not exceeding $30 \%$ of the charter capital of a Vietnamese commercial bank. Thus, foreign investors can participate in the share ownership of listed companies in Vietnam as a major shareholder, a strategic investor and/or a member of the management board. However, they do not play many roles in making decisions of the important issues of the company (especially in those companies of state ownership and where the State is the dominant shareholder), thereby cannot improve the performance of the company, nor can help improve corporate risk management or increase the transparency in information disclosure. It is from the weaknesses in risk management combined with limitations in protecting investors and the less transparent information environment that will spread the effects onto the whole market and thereby increasing the systemic risk in the operation of listed companies in Vietnam.

Different from foreign investors, the ownership level by domestic investors helps to reduce systemic risks on Vietnam stock market. Domestic investors can be major or small shareholders, having conditions to fully and timely grasp the general macro information of the whole market such as: inflation, interest rates, the growth of the economy, ... and convert that information into stock prices before making any investment decisions. Especially, being major shareholders, domestic investors obtain lots of internal information of the company which is not widely disclosed on the market and thus have more advantages in terms of information compared to other shareholders; therefore, they can trade based on these obtained advantages. As a result, stock price synchronocity can be limited in comparison with the general market volatility and thereby reducing system risks of the market.

In addition, when the research team controlled the variable of ownership by foreign investor in the relations between state ownership and systemic risk to consider the net effect of state ownership on systemic risk, there existed the same direction and statistically significant relations between state ownership and systemic risk in Vietnam stock market. This result was consistent with the assumption that companies with high state ownership rates commonly had low business performance, poor risk management and were subject to the impact of the State in their operational objectives. Also, the transparency and information disclosure activities in these companies were not high; shareholders representing the state capital in the companies did not pay proper attention to the corporate performance, nor have they devoted to the benefits and values of the company. Indeed, they were still dominated by other purposes. In Vietnam market, the market capitalization value of state-owned enterprises after equitization and listing of stocks on the stock market accounts for a large proportion of the total market capitalization value. The volatility in stock prices of these companies exerts a certain influence on the index fluctuations of the whole market. These characteristics contribute to increasing systemic risk on the stock market.

As a control variable, the return on equity (ROE) has a positive relation with systemic risk on the stock market. This indicates that for companies with large capital size which is mainly mobilized from borrowings and with low equity as well as using high leverage, ROE will become 
more sensitive and vulnerable to changes in systematic factors from the market such as interest rates, inflation... thereby increasing systemic risks on the market. In particular, large-scale companies where the State is the dominant shareholders with the governance mechanism of multi management levels often react more slowly to market volatilities.

Company size (SIZE) has an inverse relation with systemic risk on the stock market. The fact that stock price volatility of large-scale companies in the market often directs the fluctuations in stock prices of other companies and is an important indicator to reflect the trends of market volatility. In addition, large-scale companies often have greater transparency in information disclosure, better corporate governance and a more transparent corporate information environment than small-scale ones. This helps the stock prices of the company reflect most of the information belonging to the company and less represent the general information of the market, thereby reducing systemic risks on the market.

\section{References}

Acharya, V. V., Pedersen, L. H., Philippon, T., \& Richardson, M. P. (2010). Measuring systemic risk (Working Paper). Retrieved November 20, 2019, from New York University Stern website: http://pages.stern.nyu.edu/ /pederse/papers/MeasuringS ystemicRisk.pdf

Adrian, T., \& Brunnermeier, M. K. (2008). CoVaR (Staff Report, No.348). New York, NY: Federal Reserve Bank of New York. Retrieved from http://hdl.handle.net/10419/60863

Alaghi, K. (2011). Financial leverage and systematic risk. African Journal of Business Management, 5(15), 66486650. https://doi.org/10.5897/AJBM11.335

Amit, R., \& Livnat, J. (1988). Diversification, Capital Structure, and Systematic Risk: An Empirical Investigation. Journal of Accounting, Auditing \& Finance, $3(1)$, $19-43$. https://doi.org/10.1177/0148558X8800300103

An, H., \& Zhang, T. (2013). Stock price synchronicity, crash risk, and institutional investors. Journal of Corporate Finance, 21(C), 1-15. doi: 10.1016/j.jcorpfin.2013.01.001

Antoniadis, I., Lazarides, T. M., \& Sarrianides, N. (2010), Ownership and performance in the Greek banking sector. Paper presented at the International Conference on Applied Economics - ICOAE 2010, Athens, Greece. Retrieved November 20, 2019, from http://icoae.com/?cat $=12$

Bordo, M. D., Mizrach, B., \& Schwartz, A. J. (1998). Real versus pseudo-international systemic risk: some lessons from history. Review of Pacific Basin Financial Markets and Policies, 1(1), 31-58. https://doi.org/10.1142/S0219091598000053

Brunnermeier, M. K., Goodhart, C., Crocket, A., Persaud, A., \& Shin, H. S. (2009). The Fundamental Principles of Financial Regulation: 11th Geneva Report on the World Economy. Centre for Economic Policy Research (CEPR), London, UK. ISBN 9780955700972

Brockman, P., \& Yan, X. (2009). Block ownership and firm-specific information. Journal of Banking and Finance, 33(2), 308-316. https://doi.org/10.1016/j.jbankfin.2008.08.011

Fernandes, N., \& Ferreira, M. A. (2008). Does international cross-listing improve the information environment. Journal of Financial Economics, 88(2), 216-244. https://doi.org/10.1016/j.jfineco.2007.06.002

Gujarati, D. N. (2003). Basic econometrics (4 ${ }^{\text {th }}$ ed.). New York, NY: McGraw-Hill.

Gul, F. A., Kim, J. B., \& Qiu, A. A. (2010). Ownership concentration, foreign shareholding, audit quality and stock price synchronicity: evidence from China. Journal of Financial Economics, 95(3), 425-442. https://doi.org/10.1016/j.jfineco.2009.11.005

Hamdi, B. N., \& Cosset, J. C. (2014). State ownership, political institutions, and stock price informativeness: Evidence from Privatization. Journal of Corporate Finance, 29(C), 179-199. doi: 10.1016/j.jcorpfin.2014.10.004

He, W., Li, D., Shen, J., \& Zhang, B. (2013). Large foreign ownership and stock price informativeness around the world. Journal of International Money and Finance, 36, 211-230. doi: 10.1016/j.jimonfin.2013.04.002

He, W., \& Shen, J. (2014). Do foreign investors improve informational efficiency of stock prices? Evidence from Japan. Pacific-Basin Finance Journal, 27(C), 32-48. doi: 10.1016/j.pacfin.2014.01.005

Hou, W., Kuo, J. M., \& Lee, E. (2012). The impact of state ownership on share price informativeness: the case of the split share structure reform in China. The British Accounting Review, 44(4), 248-261. https://doi.org/10.1016/j.bar.2012.09.003

IOSCO. (2012). Systemic Risk Identification in Securities Markets (Staff Working Paper 2012/1). Madrid, Spain: IOSCO Research Department. Retrieved November 20, 2019, from https://www.iosco.org/library/pubdocs/pdf/IOSCOPD4 61.pdf

Jiang, L., \& Kim, J. B. (2004). Foreign equity ownership and information asymmetry: evidence from Japan. Journal of International Financial Management \& Accounting, 15(3), 185-211. https://doi.org/10.1111/j.1467-646X.2004.00107.x 
Jin, L., \& Myers, S. C. (2006). R ${ }^{2}$ around the world: New theory and new tests. Journal of Financial Economics, 79(2), 257-292.

Kim, J. B., \& Shi, H. (2009). International financial reporting standards,

analyst following, institutional infrastructure, and stock price

synchronicity (City University of Hong Kong and Fudan University Working Paper).

Kim, P. K., Rasinh, D., \& Tasnim, R. B. (2012). A Review of Corporate Governance: Ownership Structure of Domestic-Owned Banks in Term of Government Connected Ownership, and Foreign Ownership of Commercial Banks in Malaysia. Journal of Organizational Management Studies, 2012. doi: $10.5171 / 2012.335681$

Kiruri, R. M. (2013). The effect of ownership structure on bank profitability in Kenya. European Journal of Management Sciences and Economics, 1(2), 116-127.

Lee, J. S., \& Jang, S. S. (2007). The systematic-risk determinants of the US airline industry. Tourism Management, 28(2), https://doi.org/10.1016/j.tourman.2006.03.012
Morck, R., Yeung, B., \& Yu, W. (2000). The information content of stock markets: Why do emerging markets have synchronous stock price movement? Journal of Financial Economics, 58(1-2), 215-260.

Nguyen, H. S., Tran, T. T. T., Dinh, X. C., Lai, A. H., \& Pham, B. K. (2015). Impact of Ownership Structure and Bank Performance - An Empirical Test in Vietnamese Banks. International Journal of Financial Research, 6(4), 123-133. https://doi.org/10.5430/ijfr.v6n4p123

Oosterloo, S., \& de Haan, J. (2003). A survey of institutional frameworks for financial stability (No. 104). Netherlands Central Bank, Research Department.

Szpunar, P. J., \& Głogowski, A. (2012). Lending in foreign currencies as a systemic risk. Macro-prudential Commentaries, Issue No.4, European Systemic Risk Board. Retrieved November 20, 2019, from https://www.esrb.europa.eu/pub/pdf/commentaries/ESR B_commentary_1212.pdf?541f7be0c3cca0d0b75101e2 92d18456

Wen, Y., \& Jia, J. (2010). Institutional ownership,managerial ownership and dividend policy in bank holding companies. International Review of Accounting, Banking and Finance, 2(1), 8-21 